\title{
The Impact of Mobile Learning on EFL Students' Learning Behaviors and Perceptions: From Content Delivery to Blended Interaction
}

\author{
Vo Thuy Linh ${ }^{1} \&$ Nguyen Ngoc Vu \\ ${ }^{1}$ Sai Gon University, Ho Chi Minh City, Vietnam \\ ${ }^{2}$ Hoa Sen University, Ho Chi Minh City, Vietnam \\ Correspondence: Vo Thuy Linh, Sai Gon University, 273 An Duong Vuong, District 5, Ho Chi Minh city, 748000, \\ Vietnam, Tel: 84-93-970-9018. E-mail: vtlinh@sgu.edu.vn \\ Received: October 12, 2020 \\ Accepted: November 19, 2020 \\ Online Published: January 13, 2021 \\ doi:10.5430/irhe.v5n4p25 \\ URL: https://doi.org/10.5430/irhe.v5n4p25
}

\begin{abstract}
Mobile learning (M - learning) emerges as the essential mark of technological revolution 4.0 and the great development of modern technology. It has proved that their smart functions were accompanied by the rapid expansion of mobile devices to support learning of learners everywhere and every time. Although mobile technology is expected to apply suitably to teaching and learning, the capacity of English as a Foreign Language (EFL) students to use mobile devices to support their English learning needs to be thoroughly evaluated. This paper is to present how EFL learners at a Vietnam University can exploit mobile technology by questionnaire through a survey of 300 EFL students. The investigation took place during the second semester of the 2018 - 2019 school year. The quantitative approach has been used to gather and analyze data, and results have shown that EFL students are confident of learning English through mobile devices through their use of mobile technology. This shows that learning English by mobile devices is feasible and has got positive perceptions from the students. Furthermore, the research results are expected to contribute as a theoretical background as reference for future researches related to mobile learning applications.
\end{abstract}

Keywords: mobile learning, EFL students, flipped classroom, technology acceptance model

\section{Introduction}

As English has been an international instrument of human communication. It is indispensible to learn English. However, learners do not have time to learn English and practice it at university or English classes. It is difficult for busy learners who vary in ages, levels, professions, etc. Same, they cannot spend time learning English from the books and have no time for such learning method in the busy situation of current education and society in Vietnam, especially for EFL students at a university in Ho Chi Minh City. Clearly, EFL students need to be helped by a flexible and successful method of learning English that can help them learn wherever and whenever they can. Therefore, a positive and simple approach to learning should be followed to enable learners every time and everywhere to learn English.

Nowadays, the world's ICT market offers easy access for mobile devices such as smartphones, Ipods, tablets, laptops, etc. thanks to their "handy and compact" nature (Bhatti, 2015). Due to the improvement of mobile devices' forms and functions, they have attached material data sources that support human contact, information, demands that involve learning in the offline and online environments every time and everywhere. Mobile devices can provide learners at different levels with tremendous wealth of knowledge via the internet as well as learning opportunities (Thao, 2014). Nevertheless, the participation of mobile learning activities and learners' readiness for learning English through mobile technology should be investigated. In addition, the willingness of learners to use their mobile devices should be measured. Therefore, this study is conducted to evaluate the efficiency of EFL students to use mobile devices to support their English learning and suggest some other aspects for future researches relevant to learning and teaching English. The main purpose of this study is to answer the following research question "How is it possible for EFL students to use mobile devices to help their English learning?" 


\section{Literature Review}

\subsection{Mobile Learning (M-learning)}

M-learning was growing at such a non-stop pace that surpassed the standards of information and communication technology (ICT) experts. Under various views of different authors (Quinn 2000; Vu 2016a), mobile learning is the way that a person learns something using mobile devices such as Palms, Windows CE computers, and even his digital cell phone. Sharing a similar opinion, Sharples (2006) claims that mobile education means the use of mobile technologies. The following definition also proves the practicality of mobile education in a technology-proliferating society: "Any learning that occurs when the learner is not at a fixed, predetermined location or learning that occurs when the learner takes advantage of the learning opportunities offered by mobile technologies" (O'Malley et al, 2010).

Lots of documentation should be completed to incorporate the optimal M-learning program. This article tries to survey the attitudes of teachers on M-learning and considers how they teach English via mobile devices as the framework applicable for future mobile learning application study. As the topic of this research, there are many previous studies employed by previous authors in Vietnam and around the world such as Linh et al. (2017), Vu (2016b), Khanh and Gim (2014), and Kuciapski (2016), etc. Such researchers, however, survey expectations, behaviors, and acceptance of high school English students without examining EFL students' ability to use mobile devices to support their English learning. Therefore, this survey aims at filling this void and gathering new results on the willingness of EFL learners to use mobile technology for their mobile learning in English as well as providing a unique reference for the next relevant researches.

In the era of revolution 4.0, mobile technologies became ubiquitous in human life overcoming time and space constraints through their multiple characteristics. In particular, it is a powerful innovation in education globally. Chen et al. (2002) understand specific features of mobile technology with advantages not offered in scaffold-learning through other distance learning technology. Mobile learning can significantly support learners in learning English, thanks to many advantages.

Evidently, mobile devices become multimedia access tools, connectivity tools, capture tools; representation and analysis tools offering benefit characteristics for teaching and learning that Pollara (2011) emphasizes. Accordingly, mobile learning devices support for students' motivation, encourage their sense of responsibility, improve their commitment and promote their learning in general, in learning English particularly and retention; help increasing individual's organizational skills and self-regulatory capacity of learning through planning applications: support communication, collaboration and knowledge building via real-time data; offer both individualized and social interactive learning environment and promote student-student and student-teacher interactions; improve learners' reasoning skills and self-confidence; support independent, constructivist and contextualized learning; offer active and experiential learning opportunities allowing quick note-taking through photos, sound and video recording. Thank to these characteristics, Naismith et al. (2004) identified several other benefits of mobile learning for English learning in particular and in education in general.

However, mobile devices also bring some challenges for teaching and learning English as explained by Pollara (2011): (1) Mobility poses challenges to usual teaching practices; (2) Informality can make mobile learning lose its benefits if it is too widespread; (3) Ownership poses challenges to institutional control; (4) learning over time offers the Mobile devices clearly are multimedia access tools, communication tools, capture tools. Pollara (2011) emphasizes this as supporting the motivation of students, fostering their sense of responsibility, enhancing their engagement and promoting their learning in general, particularly in English learning and retention. In addition, mobile devices also present some of the challenges of teaching and learning English stated by Pollara (2011): (1) Mobility poses challenges to the normal teaching practices; (2) Informality can make mobile learning lose its advantages if it does not take advantage of this. The small size of mobile devices also enables mobility and portability anytime and anywhere; however, over time accessing screens for mobile devices can affect the eyes and rain of users. Therefore, consumers have to be cautious and disciplined to use reasonable and practical mobile devices for their learning. Also, the small size of mobile devices allows for mobility and portability anytime and anywhere; however, contacting mobile devices' screens over time will affect users' eyes and brain. Therefore, users need to be careful and balance to use mobile devices for their learning activities.

Mobile devices provide a diverse and positive environment for teachers to teach English anywhere and at any time, from the relationship between mobile learning and teaching English as well as the importance and challenges of mobile education on learning English. Based on the purpose of current study, the researcher follows the Technology Acceptance Model (TAM) (Davis, 1989) to design the questionnaire contents. 


\subsection{Technology Acceptance Model (TAM)}

Davis (1989) discusses the Technology Acceptance Model (TAM) to test the perceived usefulness and user friendliness of technology handlers. Napitupulu et al. (2017) believe that the TAM was seen as an essential research model for assessing the factors of acceptance and utilization of information technology among users, and was the most well - adopted model. Raaij and Schepers (2008) also agree that TAM is a comprehensive theory among many models in the literature on the information systems to describe the acceptance of information technology by individuals. Because of the persuasiveness and evidence associated with user attitudes, psychology, and expectations, the researcher should apply this theory to survey the attitudes of ELF teachers towards mobile learning as illustrated in Figure 1.

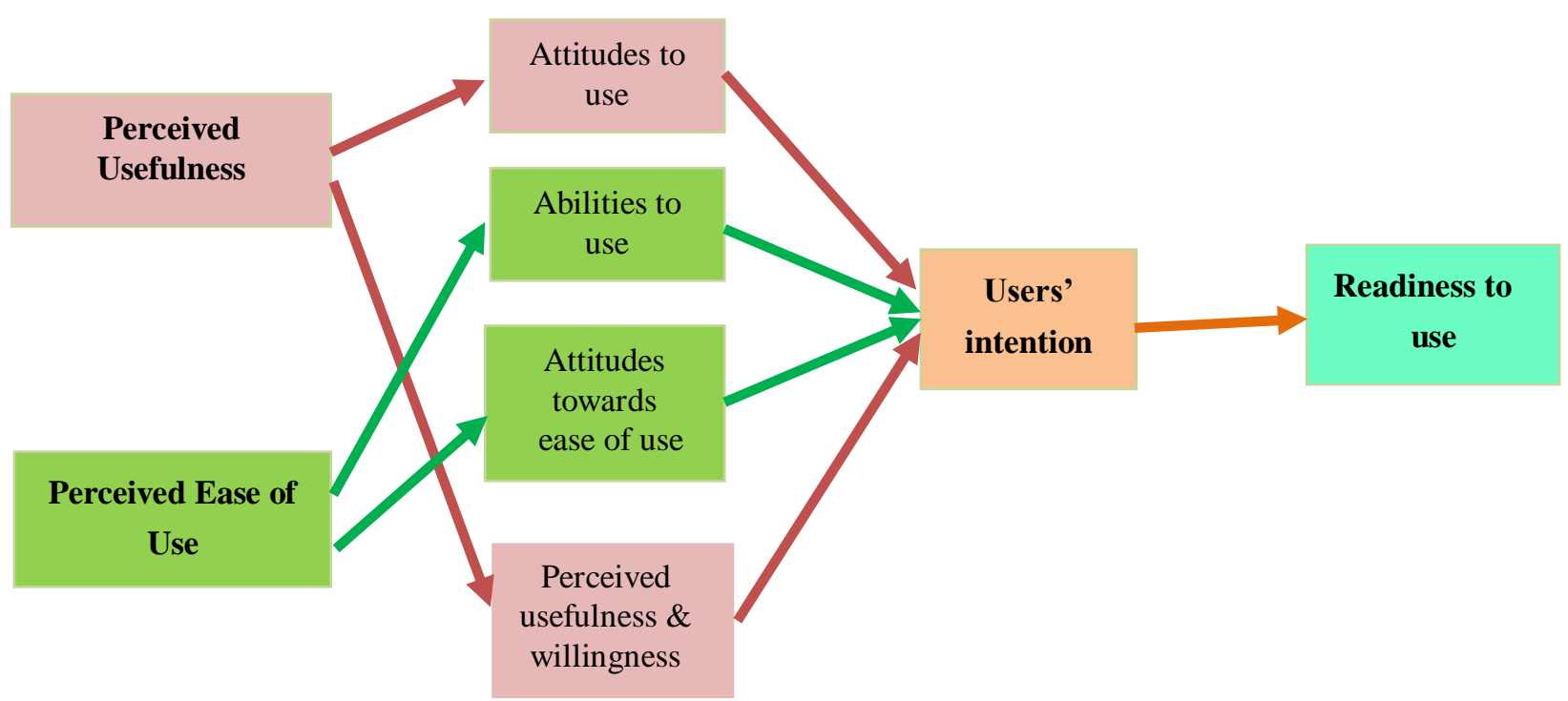

Figure 1. Model of readiness to use mobile technology in EFL learning and teaching

Following the current study content, the above TAM was explained as Perceived Usefulness (PU): The extent a person believes in using technology to improve his or her learning. According to Lefievre (2012), it is used to explore the attitudes of EFL teachers toward the usefulness of mobile devices in teaching English skills for EFL students such as listening, speaking, reading, writing and grammar. Perceived ease of use (PEOU) is the extent to which a person believes that he or she is confident using technology to learn. Similarly, PEOU is used to denote the opinion of EFL teachers regarding ease of use of mobile devices in English teaching. Attitude towards the use of technology (ATUT) is represented by the attitudes of EFL teachers towards the use of mobile technology in English teaching. The intent to use technology (IU) presents for the habits and propensity of EFL teachers to use portable devices to support their English teaching. One of four sub - factors released from PU, the ability to use, was chosen in this research to investigate the ability of EFL students to use mobile devices in English listening by questionnaire. In addition, survey data were collected and analyzed to discover the answer to the research question "How can EFL students use mobile devices to help their English language learning?"

\section{Research Methodology}

The survey is being carried out at the University within two weeks of the second semester of 2018 - 2019. With twelve questions (15 minutes), the questionnaire (5 scales: strongly agree, agree, no idea, disagree, strongly disagree) was designed to evaluate the ability of EFL students to use mobile devices in English learning. In the light of this summary of the study, the participants are all 300 university EFL students.

The questionnaire is intended as the instrument of this study with the aim of evaluating the ability of EFL students to use mobile devices in English learning. The questionnaire was structured in correlative form with twelve sentences. Every assertion followed by five Likert scales for the participants to choose their ideas by writing only a tick into one cell of columns of ideas (1 ) strongly disagree (SD), (2 ) disagree (D), (3) no plans (NP), (4) agree (A), and (5 ) strongly agree (SA). 


\section{Results and Discussion}

The results of the questionnaire were revealed by number of sticking scale turns of each statement obtained through a quantitative approach. The poll's content is to answer the research question, "How are EFL students in a position to use mobile devices to help their English learning?" The researcher analyzes the proportion of the ideas of the participants to determine their actions and acceptance of $\mathrm{M}$ - learning for each argument.

Table 1. Participants' answers for the questionnaire

\begin{tabular}{|c|c|c|c|c|c|}
\hline Statement & $\begin{array}{l}\text { Strongly } \\
\text { disagree }\end{array}$ & Disagree & No plans & Agree & $\begin{array}{c}\text { Strongly } \\
\text { agree }\end{array}$ \\
\hline $\begin{array}{l}\text { 1. I can use a mobile device as a useful one (calculator, notes, } \\
\text { alert/alarm, calling, messages, photos, video, recording, etc.) }\end{array}$ & $2.7 \%$ & $0.3 \%$ & $9.3 \%$ & $60 \%$ & $27.7 \%$ \\
\hline 2. I can access the internet from a mobile device in English learning. & $3 \%$ & $2.3 \%$ & $10.3 \%$ & $\begin{array}{c}58.7 \\
\%\end{array}$ & $25.7 \%$ \\
\hline $\begin{array}{l}\text { 3. I can download applications to learn something new in my English } \\
\text { lessons through mobile devices. }\end{array}$ & $2 \%$ & $0.3 \%$ & $9.3 \%$ & $\begin{array}{c}59.7 \\
\%\end{array}$ & $28.7 \%$ \\
\hline $\begin{array}{l}\text { 4. I can download a specialized application to serve learning English on } \\
\text { a mobile device. }\end{array}$ & $2 \%$ & $0.7 \%$ & $8.7 \%$ & $\begin{array}{c}62.3 \\
\%\end{array}$ & $26.3 \%$ \\
\hline $\begin{array}{l}\text { 5. I can use mobile devices to look up something that I did not } \\
\text { understand during English lessons (new words, sentences, etc). }\end{array}$ & $1.7 \%$ & $0 \%$ & $8 \%$ & $59 \%$ & $31.3 \%$ \\
\hline $\begin{array}{l}\text { 6. I can access a social networking site (face book, zalo, line, we chat, } \\
\text { blog, etc.) on a mobile device to learn English. }\end{array}$ & $2.3 \%$ & $1.7 \%$ & $14.3 \%$ & $\begin{array}{c}57.7 \\
\%\end{array}$ & $24 \%$ \\
\hline $\begin{array}{l}\text { 7. I can play an educational game for practicing English (e.g. bingo, fast } \\
\text { English, hidden object, concentration, etc.) on my mobile devices. }\end{array}$ & $2.7 \%$ & $0.7 \%$ & $13 \%$ & $57 \%$ & $26.7 \%$ \\
\hline 8. I can read a text or article (word, PDF) on my mobile devices. & $2.7 \%$ & $4.3 \%$ & $14 \%$ & $\begin{array}{c}59.3 \\
\%\end{array}$ & $19.7 \%$ \\
\hline $\begin{array}{l}\text { 9. I can exchange with my classmates about a content of an English } \\
\text { lesson through my mobile devices. }\end{array}$ & $2.3 \%$ & $1.3 \%$ & $14.7 \%$ & $62 \%$ & $19.7 \%$ \\
\hline $\begin{array}{l}\text { 10. I can exchange with my teachers about a content of an English } \\
\text { lesson through my mobile devices. }\end{array}$ & $2.3 \%$ & $1.7 \%$ & $17.7 \%$ & $\begin{array}{c}57.3 \\
\%\end{array}$ & $21 \%$ \\
\hline $\begin{array}{l}\text { 11. I can participate in educational forums (e.g. Moodle) on my mobile } \\
\text { devices to learn English. }\end{array}$ & $2.7 \%$ & $1.7 \%$ & $21.7 \%$ & $\begin{array}{c}55.7 \\
\%\end{array}$ & $18.3 \%$ \\
\hline $\begin{array}{l}\text { 12. I can use my mobile devices as a handy learning tool online or } \\
\text { offline to learn English everywhere and every time. }\end{array}$ & $2.3 \%$ & $1.7 \%$ & $13.7 \%$ & $\begin{array}{c}57.3 \\
\%\end{array}$ & $25 \%$ \\
\hline
\end{tabular}

Table 1. EFL students' abilities to use mobile devices to support their English learning

The table above shows the percentage of questionnaire's answers after the survey. These figures indicate the total number of respondents from the research sample chose Likert scales of each statement. The results indicate that the majority of faculty members (>80\%) have good attitudes towards the use of mobile devices in learning English. Twelve statements were summarized in the chart below: 


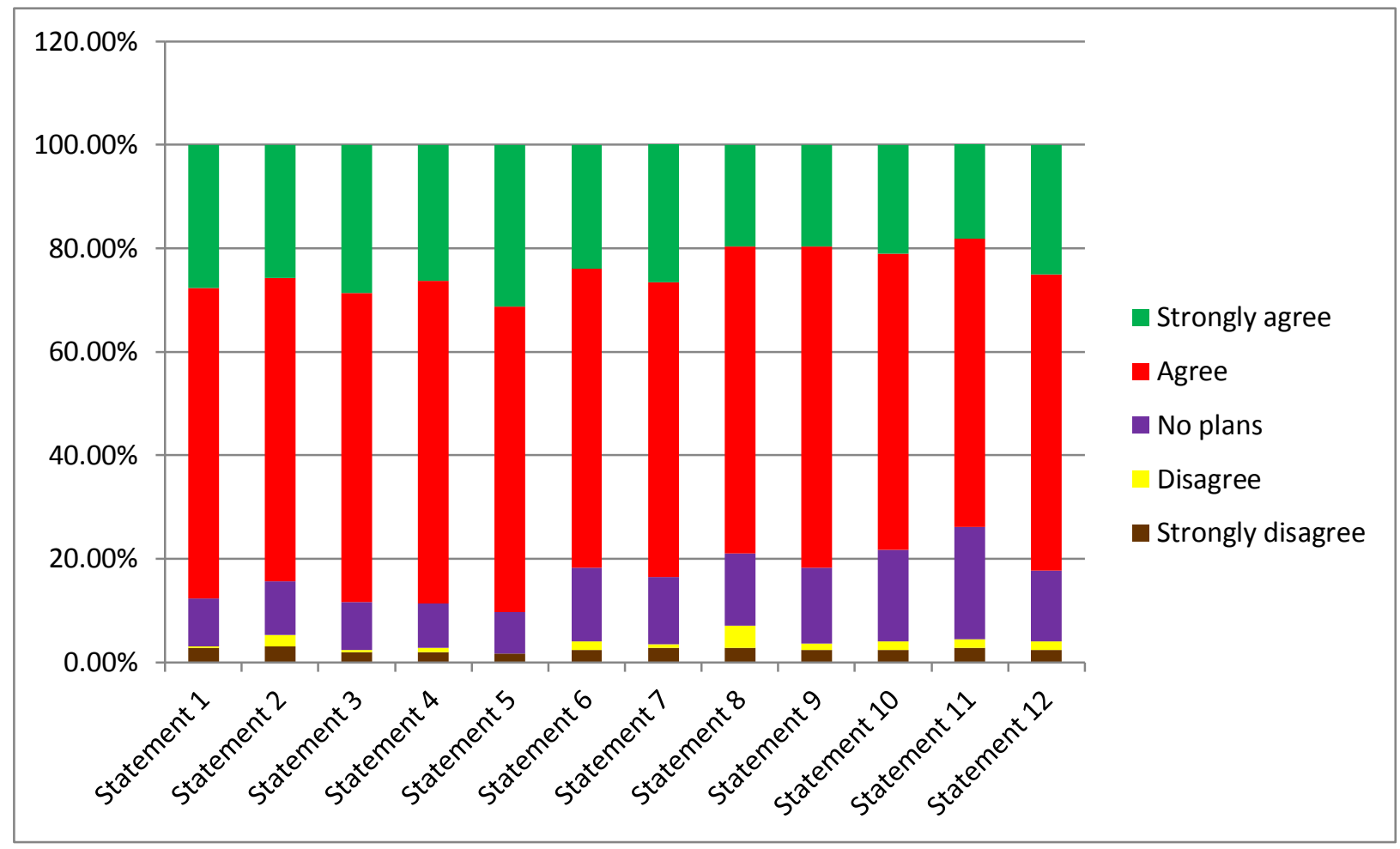

Chart 1. Participants' answers for the questionnaire

From the data in Chart 1 it can be seen that the majority of EFL students report using their mobile devices to perform all of the functions listed here. On average, more than 80 percent of participants believe that they can skillfully employ their mobile devices at the rates raised through Likert scales, so are strongly in agreement with each statement. Students can use a mobile device as a helpful tool (60 percent agree and 27.7 percent agree strongly), they can also access the internet ( 60 percent agree and 27.7 percent agree strongly), download software to learn something new (58.7 percent agree and 25.7 percent agree strongly), download a specific application (59.7 percent agree and 28.7 percent agree strongly), use mobile devices. Obviously, students may use mobile apps that acquire various functions to do several things to promote English learning. Mobile devices, particularly the students, are becoming popular for all ages. They can be useful on mobile devices. Overall, these findings suggest that it is easier for students to learn English by mobile devices. The majority of students are equipped with technical skills, and they tend to be able to use mobile devices, clearly, they are eager to use mobile devices to learn English.

To sum up, learning English with mobile devices seems easy for students as the level of disagreement in turn of twelve statements are as high. Moreover, the highest proportion of students with no idea hits almost a quarter (21.7 percent), which shows only a few people who might not be involved in showing their ability to use mobile devices, they might not necessarily see their ability to use technology, because they do not want to be silent, perhaps.

As a word, PEOU of TAM of Venkatesh and Davis (1996) and TAM2 of Venkatesh and Davis (2000) was defined that EFL teachers perceive that using mobile devices in teaching English is exciting. PU of TAM was presented that most EFL teachers concur using mobile devices to support teaching English skills for EFL students. They agree and admit that using mobile technology is useful in teaching listening, speaking, reading, writing, vocabulary and grammar.

The EFL teachers generally have good behavior in learning English via mobile devices. In addition, they assume M learning can effectively support English learning through a high percentage of scales. The participants are able to use mobile technology to support their English learning. The questionnaire results found a satisfactory answer to the research question "How are EFL students in a position to use mobile devices to support their English learning?" The results of the scale levels draw nearly students from controlling mobile devices in depth and overcoming technical errors of their devices when learning English. For each statement related to the ability to use English through mobile devices, it was addressed through the proportion of nearly more than 80 percent of choosing agreement scale. Therefore, the data analysis results indicated the capacities of the EFL students to use technology. EFL students in fact 
show that it is easy enough to use mobile devices to support their English learning.

In the range of study, this writing holds the survey on EFL students' abilities to use mobile devices for learning English. Moreover, researching mobile learning here is just halted at the survey on students' capacities to use mobile devices to learn English; EFL teachers' abilities to use mobile devices have not still been implemented. The current research has been related to those of Linh et al. (2017), Khanh and Gim (2014), Pollara (2011), Aish and Love (2013), Kuciapski (2016). They employed teachers' and learners' perceptions and abilities to use mobile devices in teaching and learning language in general, for English in particular. Also, good manipulation on mobile devices is also believed that mobile learning can create motivation in teachers' teaching English as well as support students to learn every time and everywhere.

EFL students generally nearly use mobile devices to learn English well via. In addition, they are comfortable in solving common technical errors on their mobile devices to effectively learn English through a high percentage of scales. The participants believed that their use of mobile devices helped them to learn English well. The questionnaire results found that the answer to the research question "How can EFL students use mobile devices to help their learning of English is satisfied?" In depth, the results of the scale levels show approximately students have strong ability to learn English using mobile devices. Nearly 80 percent of participants accept scale for each statement showed that it is not difficult for them to learn English through mobile devices. Therefore, the aim of EFL students to use technology (IU) was indicated via the data analysis results as feasible. EFL students are in reality inclined to accept learning English through mobile devices.

\section{Conclusions}

In short, at the current university, EFL students exploit smart mobile device functions to support their English learning. Since some limitations of this research have not yet been conducted on mobile learning applications, they are expected to be implemented in future studies to serve in particular to teach and learn English at present university and in education in Vietnam and the world at large. In addition, the researchers would like to recommend funding and policies for mobile learning applications; mobile learning should be designed and evaluated for students to achieve practical convenient learning at university and elsewhere.

\section{References}

Abu-Al-Aish, A., \& Love, S. (2013). Factors Influencing Students' Acceptance of M-Learning: An Investigation in Higher Education. International Review of Research in Open and Distance Learning, 14(5). 83-107. https://doi.org/10.19173/irrodl.v14i5.1631

Chen, Y-S., Chen, T-S., \& Huang, C-J. (2002). SOM. Spiral-Fat-Tree-Based on-Demand Multicast Protocol in a Wireless Ad-Hoc Network. Computer Communications, 25(17), 1684-1695.

Davis, F. D. (1989). Perceived usefulness, perceived ease of use, and user acceptance of information technology. MIS Quarterly, 13(3), 319-340.

Feser, J. (2010). MLearning Is Not eLearning on A Mobile Device |Float. Retrieved from https://gowithoat.com/2010/04/mlearning-is-not-elearning-on-amobile-device/

Iqbal, S., \& Bhatti, Z. A. (2015). An Investigation of University Student Readiness towards M-learning using Technology Acceptance Model. International Review of Research in Open and Distributed Learning, 16(4).

Kuciapski, M. (2016). Students' Acceptance of m-Learning for Higher Education - UTAUT Model Validation. Information Systems: Development, Research, Applications, Education, 264,155-166.

Lefievre, V. (2012). Gender Differences in Acceptance by Students of Training Software for Office Tools. ATINER's Conference Paper Series, No: EDU2012-0138 Gender. Retrieved from https://www.atiner.gr/papers/EDU2012-0138.pdf

Naismith, L., Lonsdale, P., Vavoula, G., \& Sharples, M. (2004). Literature Review in Mobile Technologies and Learning. Futurelab Series, University of Birmingham. Retrieved from https://lra.le.ac.uk/jspui/bitstream/2381/8132/4/ \%5B08\%5DMo bile_Review\%5B1\%5D.pdf

Napitupulu, D., Kadar, J. A., \& Jati, R. K. (2017). Validity Testing of Technology Acceptance Model Based on Factor Analysis Approach. Indonesian Journal of Electrical Engineering and Computer Science, 5(3), 697-704. https://doi.org/10.11591/ijeecs.v5.i3

Ngo, T. V. K., \& Gwangyong, G. (2014). Factors influencing mobile-learning adoption intention: an empirical investigation in high education. Ph.D. Thesis. 
O’Malley, C., Vavoula, G., Glew, J., Taylor, J., Sharples, M., \& Lefrere, P. (2003). Guidelines for learning/teaching/tutoring in a mobile environment. MOBIlearn Deliverable, 4. Retrieved from https://files.eric.ed.gov/fulltext/E J932239.pdf

Pollara, P. C. (2011). Mobile learning in higher education: a glimpse and a comparison of student and faculty readiness, attitudes and perceptions. LSU Doctoral Dissertations, 2349. Retrieved from http://digitalcommons.lsu.edu/gradschooldisserta tions/2349

Quinn, C. (2000). mLearning: Mobile, wireless, in your pocket learning. LineZine, Fall 2000. Retrieved August 28, 2007, from http://www.linezine.com/2.1/featur es/cqm m wi yp.htm

Raaij, V. E. M., \& Schepers, J. J. L. (2008). The Acceptance and Use of a Virtual Learning Environment in China. Computers \& Education, 50, 838-852. https://doi.org/10.1016/j.compedu.2006.09.001

Sharples, M. (2006). Big issues in mobile learning. Report. Nottingham: Kaleidoscope Research.

Tobias, J. L., Valiente, J. R., \& Reich, J. (2020). Studying Learner Behavior in Online Courses With Free Certificate Coupons: Results From Two Case Studies. International Review of research in Open and Distributed Learning. Retrieved from http://www.irrodl.org/index.php/irrodl/issue/view/101/12

Trinh, T. P. T. (2014). The exploitation of applications on mobile phones to support grade 12 students in high schools in mathematics self-study. The Vietnam Institute of educational sciences. Ph.D. Thesis.

Vo, T. L. (2017). Surveying and assessing Sai Gon university English pedagogy students' attitudes towards M-learning. Scientific Journal of Saigon University, 33(58).

$\mathrm{Vu}, \mathrm{N}$. N. (2016a). Mobile learning in language teaching context of Vietnam: An evaluation of students' readiness. Journal of Science, HCMC University of Education, 7(85), 16-27.

$\mathrm{Vu}, \mathrm{N}$. N. (2016b). An investigation of Vietnamese students' learning styles in online language learning. Journal of Science, HCMC University of Education, 1(79), 25-34.

\section{Copyrights}

Copyright for this article is retained by the author(s), with first publication rights granted to the journal.

This is an open-access article distributed under the terms and conditions of the Creative Commons Attribution license (http://creativecommons.org/licenses/by/4.0/). 